\title{
Seroprevalence of Bordetella pertussis in pediatric healthcare workers at the Hospital Infantil de México Federico Gómez
}

\author{
Esperanza Navarrete, Almudena Laris-González, Arturo D. Castro-Díaz, Gustavo Rosales-Pedraza, \\ Sarbelio Moreno-Espinosa and Daniela de la Rosa-Zamboni* \\ Hospital Infantil de México Federico Gómez, Mexico City, Mexico
}

\begin{abstract}
Background: Bordetella pertussis is the causative agent of pertussis, a disease that is preventable by vaccination buthas a high mortality, particularly in children $<6$ months. Reports of pertussis outbreaks in hospitals show that the index case is usually an adult. In adults, the disease manifests mainly with persistent cough. The purpose of this study was to determine the seroprevalence of B. pertussis in the health personnel of a pediatric hospital in a country where vaccination of this staff is not considered mandatory. Methods: Nursing staff and resident doctors who were involved in direct treatment ${ }^{\star}$ with hospitalized patients participated in the study. Each participant was screened for immunoglobulin G anti-pertussis toxin antibodies (anti-PT), and a questionnaire was applied for clinical and demographic data. Results: Ninety-three individuals were included, of which $85 \%$ were nurses, median age 35 years (interquartile range: 29-42.5). The participants worked in the emergency department (21.5\%), in the Pediatric Intensive Care Unit (8.6\%), and in the Neonatal Intensive Care Unit (6.5\%). Detectable titers of anti-TP antibodies were found in $18.3 \%$, of which $53 \%$ presented titles suggestive of recent infection and only $23.5 \%$ cough $>2$ weeks of duration. Conclusions: Health personnel are at risk of suffering from the disease and be potential transmitters to infants, who may die from this cause. This study suggests that the current vaccination policies in health personnel should be modified to determine the compulsory nature of the vaccination, especially in those individuals in charge of the care of the pediatric population.
\end{abstract}

Key words: Seroprevalence. Bordetella pertussis. Healthcare professional.

\section{Seroprevalencia de Bordetella pertussis en el personal de enfermería y médicos residentes del Hospital Infantil de México Federico Gómez}

\section{Resumen}

Introducción: Bordetella pertussis es el agente causal de la tosferina, una enfermedad de alta letalidad, especialmente en menores de 6 meses, pero prevenible mediante la vacunación. Los reportes en hospitales de brotes de tosferina muestran que el caso índice suelen ser personas adultas. En adultos, la enfermedad se manifiesta principalmente con tos persistente. El propósito de este estudio fue conocer la seroprevalencia de B. pertussis en el personal de salud de un hospital pédiátrico en un país donde aún no se considera la vacunación obligatoria para los empleados. Métodos: Participaron personal

Correspondence:

${ }^{*}$ Daniela de la Rosa-Zamboni

E-mail: rzdaniela@ hotmail.com

2444-3409/@ 2019. Hospital Infantil de México Federico Gómez, published by Permanyer México SA de CV, all rights reserved.
Date of reception: 02-10-2018

Date of acceptance: 21-01-2019

DOI: 10.24875/BMHIME.M19000061
Available online: $14-01-2020$ Bol Med Hosp Infant Mex. 2019;76:113-118 www.bmhim.com 
de enfermería y médicos residentes en trato directo con pacientes hospitalizados. A cada participante se le realizó detección de anticuerpos inmunoglobulina G, antitoxina de pertussis (anti-TP) y se le aplicó un cuestionario para datos clínicoss y demográficos. Resultados: Se incluyeron 93 individuos, el $85 \%$ de personal de enfermería con mediana de edad dè 35 años (rango intercuartil: 29-42.5). El 21.5\% de los participantes laboraban en el Servicio de Urgencias, el $8.6 \%$, en la Unidad de Terapia Intensiva Pediátrica, el 6.5\%, en la Unidad de Cuidados Intensivos Neonatales. Se encontraron títulos detectables de anticuerpos anti-TP en el $18.3 \%$, de los cuales, el $53 \%$ presentaron títulos de infección reciente y solamente el $23.5 \%$, historia de tos de más de dos semanas de evolución. Conclusiones: El personal de salud está en riesgo de sufrir la enfermedad y de transmitirla a los lactantes, quienes pueden fallecer por esta causa. Este estudio sugiere que las políticas actuales de vacunación en personal de salud se deben de modificar para determinar obligatoriedad de la vacuna, eśpecialmente en quienes atienden a la población pediátrica.

Palabras clave: Seroprevalencia. Bordetella pertussis. Profesional de la salud.

\section{Introduction}

Bordetella pertussis is the causative agent of pertussis, a disease with high lethality that exclusively affects the upper airways of humans, which is preventable by vaccination. ${ }^{1}$ This microorganism adheres firmly to hair cells through adhesins. The pertussis toxin and the filamentous hemagglutinin are the most critical attack proteins, although the fimbrial proteins pertactin and BrkA (Bordetella resistance to killing) also participate in this process. ${ }^{2,3}$ Clinical manifestations in infants and non-immunized children are divided into three typical phases: catarrhal, paroxysmal, and convalescent. Lethality in infants is high-400 per million live births, while in children aged 1 to 3 years, it is 3 to 10 per million live births. ${ }^{4}$ In adolescents and adults, pertussis has a low severity. ${ }^{5}$

The mechanism of transmission of this bacterium is by aerosols during coughing. It was estimated that $80 \%$ of the close non-immunized contacts of a patient with pertussis could acquire the infection, for which it is considered a highly contagious disease. ${ }^{2}$

Despite efforts to prevent this disease through vaccination, pertussis continues to appear every 3 to 4 years. Recently, its incidence has been increasing. ${ }^{3}$ The World Health Organization estimates that the worldwide annual incidence of pertussis is 20 to 40 million cases and is responsible for 89,000 deaths per year. However, modeling studies estimated around 24.1 million cases and 160,000 deaths worldwide in 2014, with higher mortality in infants under one year of age. ${ }^{6}$

The age groups affected by this disease have changed: in the 40s, before the implementation of diphtheria, B. pertussis (pertussis), and tetanus (DPT) vaccine, the most affected were preschool and school children. However, currently, adolescents, adults, and infants under six months are mainly affected. In the first two groups, the cause is the loss of specific immunity with the passing of the years after the vaccination, while in infants it is by contagion from adults. ${ }^{7}$

Although the severity of pertussis is lower in adôlescents and adults, they serve as a reservoir and can transmit the infection to newborns and infants, whoare not yet protected by the vaccine against $B$. pertussis and have a higher risk of complications or dying from this disease. ${ }^{5}$ It was reported that 1 to $3 \%$ of children under six months die from pertussis. The majority of deaths that occur in this age group are in those who have not yet completed their initial vaccination schedule against $B$. pertussis. ${ }^{8-11}$ Among the risk factors for mortality are low birth weight, lower gestational age, and lower age at the onset of symptoms, as we higher white cell and lymphocyte counts. ${ }^{10}$

In pediatric hospitals, especially in places where $₹$ vaccination against pertussis in adults is not mandatory, transmission can be particularly critical: patients often encounter the risk factors mentioned above and are permanently in close contact with adults. Reports of pertussis outbreaks in hospitals show that the index case is often an adult with the disease only manifesting as a persistent cough, from weeks to months of evolution ${ }^{12}$

Currently, according to the national vaccination scheme in Mexico, prevention against pertussi $\underline{\underline{s}}$ is through the application of vaccines in children from 2 months to 12 years of age. The vaccines used in Mexico are the acellular pentavalent and the wholescell DPT vaccine. ${ }^{13}$ According to the national vaccination scheme, the pentavalent vaccine should be applied at $2,4,6$, and 18 months of age, whereas the whole-cell DPT should be applied at 4 and 12 years of age. Unfortunately, no guidelines exist for the application of reinforcements or revaccination after 12 years of age. 13 The diagnosis of $B$. pertussis in adults can be difficult due to the low specificity of the symptoms presented in this population. An analysis by polymerase chain reaction during acute disease is the ideal diagnostic 
method (61\% sensitivity and $88 \%$ specificity). ${ }^{14}$ However, pertussis may not be suspected, given the ambiguous clinical picture that may go unnoticed. ${ }^{14}$ Knowing the serological profile in a given population can provide information on recent infection, immunity secondary to vaccination or past infection. ${ }^{15}$

The participation of health personnel in pediatric hospitals becomes relevant in the chain of transmission to these vulnerable groups, who may encounter other underlying disease processes as well. In 2015, Cunegundes et al. reported recent infections of $B$. pertussis in doctors and nurses of a local hospital in Brazil. ${ }^{15}$ It is relevant to know that the vaccine against $B$. pertussis is not mandatory for health personnel in Mexico. ${ }^{16}$ Given the above and to know the relevance of the problem, the present study was conducted to knowing the seroprevalence of $B$. pertussis in health personnel of a pediatrics teaching hospital in a country where the DPT vaccine is not yet considered mandatory for health care personnel.

\section{Methods}

The Hospital Infantil de México Federico Gómez (HIMFG) is a third-level teaching hospital that serves a pediatric population with limited resources and no social security. From May to September 2015, nurses, doctors, and residents of the hospitalization services, including the Neonatal Intensive Care Unit (NICU), Pediatric Intensive Care Unit (PICU), and Emergency Department, were invited to participate in the study. A proportion of each work shift was included: around $30 \%$ of the morning shift, $30 \%$ of the evening shift, $20 \%$ of night shift A and $20 \%$ of night shift B. The personnel who refused to participate in the study did not give their consent to be sampled. Approximately three people refused to give a sample, and seven did not meet the selection criteria, or their sample was insufficient.

A blood sample of each participant was taken for the detection of pertussis antitoxin (anti-TP) IgG antibodies. Participants were interviewed, and none of the respondents reported having been vaccinated during their adult lives. An immunoadsorption-enzymatic assay ${ }^{15}$ measured the anti-TP antibodies. Antibody titers higher than $50 \mathrm{IU} / \mathrm{ml}$ were considered as a recent infection; between $4-49 \mathrm{IU} / \mathrm{ml}$, as exposure to $B$. pertussis in the last year, and $<4 \mathrm{IU} / \mathrm{ml}$, as negative to the infection. Also, each participant answered a questionnaire to evaluate sociodemographic data, history of cough of more than two weeks, time they had been working in the hospital, and their current service.
A sample size of 85 participants was calculated based on the study of Deville et al., in which $32 \%$ positivity was detected for anti-TP antibodies withan alpha error of $0.05 .{ }^{17}$

The statistical analysis was performed with the SP्SS software version 22. Continuous variables were analyzed using the Mann-Whitney $U$ test. Categorical Variables were analyzed with Pearson's $\chi^{2}$ test. A value of $p<0.05$ was considered statistically significant.

The HIMFG ethics committee approved the study protocol. Informed consent was obtained fromall participants included in the project.

\section{Results}

Ninety-three individuals were included, of which thee did not agree to participate for fear of getting blood drawn, and seven did not meet the selection criteria, or their samples were insufficient. Of the individuals included, $79.85 \%$ were of the nursing staff, and the rest $(14-15 \%)$ were residents, with a median age of 35 years (interquartile range (IR): 29-42.5) and female predominance $(90.3 \%)$. The average time of seniority in the hospital was eight years (RI: 3-19 years) and the time in their cuffrent service of two years (RI: 1-6 years). As for the shifts, $54.8 \%$ of the participants belonged to the morning shift, $33.3 \%$ to the evening shift, $3.2 \%$ to the night shift, and $8 \%$ to the mixed shift. The participants were working at the emergency department (21.5\%), at the PICU (8.6\%), at the NICU $(6.5 \%)$, and the rest in other areas of hospitalization. A history of cough lasting more than two weeks was reported by $25.8 \%$ of the participants (Table 1).

Of the sample, detectable titers of anti-TP antibodies were found in $18.3 \%(n=17)$ of the participants with 95\% confidence interval $(95 \% \mathrm{Cl})$ of $11.3-29.4$ : $47 \%$ showed antibody titers between $4-49 \mathrm{IU} / \mathrm{ml}$ and $53 \%$, figures higher than $50 \mathrm{IU} / \mathrm{ml}$ suggesting a recent infection (Fig. 1). ${ }^{12}$

Among the baseline data, the only variable that showed statistically significant differences between seropositive and seronegative participants was gender: male presented a higher prevalence of seropositivity for $B$. pertusssis (23.6\% vs. $6.6 \% ; p=0.033$ ). Age tended to be lower among the seropositive $(p=0.066)$. Although the-frequency of morning and evening workers, as well as hurses and staff in the areas of PICU and NICU, was higher among seronegative for $B$. pertussis, the difference-was not statistically significant $(p>0.1)$. The seniority of workers in their areas, as well as in the hospital, was higher among seronegative subjects. However, the difference was not statistically significant either (Table 2). 
Table 1. Sociodemographic characteristics of the population

\begin{tabular}{|c|c|}
\hline Variable & $\mathrm{n}=93$ \\
\hline Age (years)* & $35(29-42.5)$ \\
\hline $\begin{array}{l}\text { Gender } \\
\text { Female }\end{array}$ & $\begin{array}{c}n(\%) \\
84(90.3)\end{array}$ \\
\hline $\begin{array}{l}\text { Position } \\
\text { Nursing staff } \\
\text { Resident }\end{array}$ & $\begin{array}{c}n(\%) \\
85(91.4) \\
8(8.6)\end{array}$ \\
\hline Time in their current service (years) & $2(1-6)$ \\
\hline Time of seniority (years)* & $8(3-19)$ \\
\hline $\begin{array}{l}\text { Work shift } \\
\text { Morning shift } \\
\text { Evening shift } \\
\text { Night shift } \\
\text { Mixed shift }\end{array}$ & $\begin{array}{c}n(\%) \\
51(54.8) \\
31(33.3) \\
3(3.2) \\
8(8.6)\end{array}$ \\
\hline $\begin{array}{l}\text { Service } \\
\text { Hospitalization } \\
\text { Emergency } \\
\text { PICU } \\
\text { NICU }\end{array}$ & $\begin{array}{c}n(\%) \\
59(63.4) \\
20(21.5) \\
8(8.6) \\
6(6.5)\end{array}$ \\
\hline Cough > 2 weeks & $24(25.8)$ \\
\hline
\end{tabular}

*The variables are expressed as median (interquartile range). NICU, Neonatal Intensive Care Unit; PICU, Pediatric Intensive Care Unit.

\section{Discussion}

In this study, no immunity against pertussis was found in $82 \%$ of residents and nurses who work in a reference pediatric hospital. Interestingly, about one in ten showed serology profiles compatible with recent infection, and the Emergency Department personnel was the most affected.

Although vaccination against $B$. pertussis is part of the national vaccination scheme, the immunity lasts less than a decade. The last dose is generally applied at four years of age, for which adolescents and adults are susceptible to a new infection, as demonstrated in this study. ${ }^{13,14}$

Similarly, $9.7 \%$ of the evaluated workers showed anti-TP titers $>50 \mathrm{Ul} / \mathrm{ml}$, compatible with recent infection, which indicates a frequent exposure to this agent. In 2015, Cunegundes et al. reported a seroprevalence of $6.4 \%$ of high antibody titers in doctors and nurses, evidence of a recent infection. ${ }^{15}$ The findings of health personnel with serology profiles compatible with infection are significant because it has been shown that in pediatric outbreaks of $B$. pertussis, the index case is adult health personnel. ${ }^{14-16}$

Other studies have shown an even higher frequency of $B$. pertussis infection in health personnel. Deville et al.

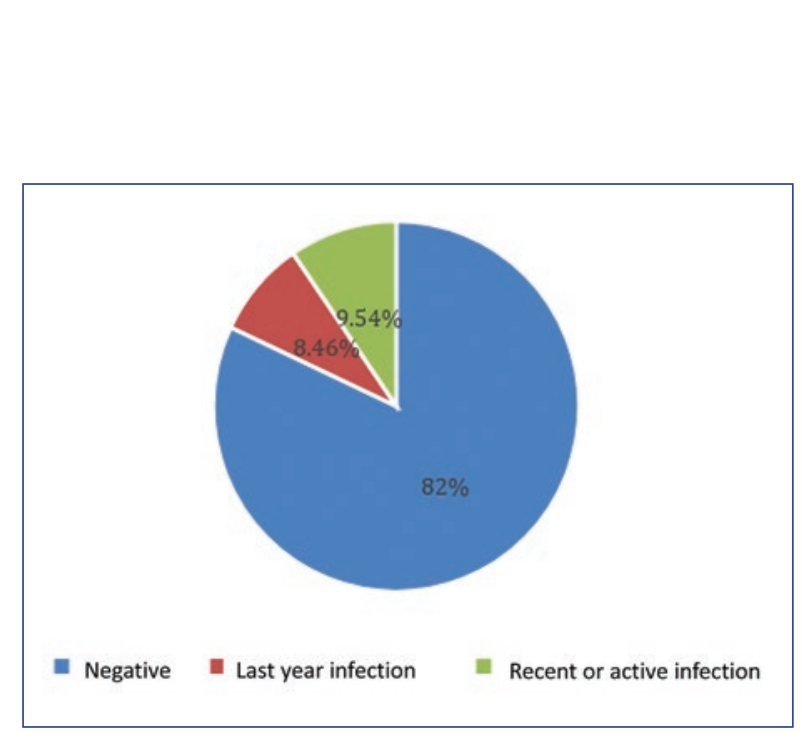

Figure 1. B. pertussis serological profile in doctors ${ }^{-a n d}$ nurses of the Hospital Infantil de México Federico Gómez. The study was considered positive for $B$. pertussis when the titers of anti-TP antibodies (pertussis toxin) were $\geq 4 \mathrm{IU} / \mathrm{ml}$ and negative when the anti-TP antibodies were $<4 \mathrm{IU} / \mathrm{ml}$. An anti-TP between $4-49 \mathrm{IU} / \mathrm{ml}$ corresponds to subjects exposed to $B$. pertussis in the last year before the study. Titles $>50 \mathrm{IU} / \mathrm{ml}$ correspond to subjects with a recent or active infection.

performed serial antibody determinations against this agent in 51 health workers for five consecutive years, and found $24-43 \%$ annual infection rate, determined by a significant increase in antibody titer. ${ }^{17}$

A metacentric study by Rodríguez et al. in Spain showed a seroprevalence of $31.2 \%$ in health service personnel, of which $3.3 \%$ of the participants had antibody titers suggesting recent infection. ${ }^{18}$

Reports on the pertussis epidemiology in Mexicoare scarce. In addition to a study carried out in secondary schools in Mexico City $^{10}$, a seroepidemiological survey conducted in 2010 in 3,344 individuals from various areas of the country revealed a $47.4 \%$ seropositifity, which was higher in children (59.3\%) compared-with adolescents and adults. Also, $21.8 \%$ of the analyzed population showed high antibody titer levels, evidence of infection or recent vaccination. ${ }^{16}$

The differences in seroprevalence between the present study and the previous reports may be seconđary to the fluctuations of the disease, which has cyctical rebounds every 3 to 4 years. Also, the difference in prevalence between different countries, and even-adherence to respiratory infection prevention measưfes ${ }^{5}$ can explain the differences. During the study, adherence to hand hygiene in the hospital was $61.6 \%$ (95\% Cl: 60-65). However, such information wašnot available in other studies.

The fact that the Emergency Department was the one with the highest proportion of participants with detectable 
Table 2. Comparison between subjects with positive and negative antibody profiles

\begin{tabular}{|c|c|c|c|}
\hline \multirow[t]{2}{*}{ Variable } & Negative & Positive & \multirow[t]{2}{*}{$p^{*}$} \\
\hline & $(n=76)$ & $(n=17)$ & \\
\hline Age in years, median (RI) & $36.5(30-44)$ & $32(29.5-36.5)$ & 0.066 \\
\hline Female, $\mathrm{n}(\%)$ & $71(93.4 \%)$ & $13(76.4 \%)$ & 0.033 \\
\hline $\begin{array}{l}\text { Position, } \mathrm{n}(\%) \\
\text { Nursing staff } \\
\text { Residents } \\
\text { Time in their current service, median (RI) } \\
\text { Time of seniority, median (RI) }\end{array}$ & $\begin{array}{c}70(92.1 \%) \\
6(7.8 \%) \\
2.5(1-7) \\
8.5(3-21)\end{array}$ & $\begin{array}{c}15(88.2 \%) \\
2(11.8 \%) \\
2(1-4.5) \\
7(2.5-11)\end{array}$ & $\begin{array}{l}0.632 \\
0.239 \\
0.182\end{array}$ \\
\hline $\begin{array}{l}\text { Shift, } \mathrm{n}(\%) \\
\text { Morning } \\
\text { Evening } \\
\text { Night } \\
\text { Mixed }\end{array}$ & $\begin{array}{c}42(55.2 \%) \\
26(34.2 \%) \\
2(2.6 \%) \\
6(7.8 \%)\end{array}$ & $\begin{array}{c}9(52.9 \%) \\
5(29.4 \%) \\
1(5.8 \%) \\
2(11.7 \%)\end{array}$ & 0.722 \\
\hline $\begin{array}{l}\text { Service, } n(\%) \\
\text { Hospitalization } \\
\text { Emergency service } \\
\text { PICU } \\
\text { NICU }\end{array}$ & $\begin{array}{c}48(63.1 \%) \\
15(19.7 \%) \\
7(9.2 \%) \\
6(7.8 \%)\end{array}$ & $\begin{array}{c}11(64.7 \%) \\
5(29.4 \%) \\
1(5.8 \%) \\
0\end{array}$ & 0.664 \\
\hline Cough > 2 weeks, N (\%) & $20(26.3 \%)$ & $4(23.5 \%)$ & 0.54 \\
\hline
\end{tabular}

${ }^{*} p<0.05$ was considered as statistically significant.

B. pertussis was considered positive when the anti-TP (pertussis toxin) antibody titers were $>4 \mathrm{IU} / \mathrm{ml}$ and negative when they were $<4 \mathrm{IU} / \mathrm{ml}$.

Variables are expressed as median, interquartile range, and percentage. For comparison, Mann Whitney $\mathrm{U}$ and $\mathrm{X}^{2}$ tests were used.

NICU, Neonatal Intensive Care Unit; PICU, Pediatric Intensive Therapy Unit.

antibodies corresponds with the results of other authors. ${ }^{16}$ The Emergency Department is the first contact with the patient. Since the pertussis clinical picture is nonspecific in many cases, the diagnosis is often not initially suspected. Coupled with the lack of adherence to precautionary measures, such as hand hygiene and mouth cover use, this facilitates transmission to health personnel.

The history of cough of more than two weeks of evolution, which showed a $23.5 \%$ prevalence in participants who had detectable anti-TP antibodies, was not significantly associated with seropositivity by $B$. pertussis. As previously described, the clinical picture of pertussis in adults is often unspecific, making the diagnosis and management difficult in this population, in which no clinical manifestations were observed in more than three-quarters of the cases. Consequently, hospital transmission is facilitating. ${ }^{13,19}$

The low seropositivity prevalence documented in this study reflects a large proportion of the population susceptible to the disease among hospital healthcare workers, as well as the difficulty for early clinical diagnosis. ${ }^{17,20}$ Overall, the results suggest that it is necessary to implement strategies for pertussis prevention. Among these strategies, vaccination reinforcements should be considered in healthcare personnel21, as recommended in countries such as Germany and the USA. ${ }^{22}$ This will protect both healthcare workers and patients and will prevent hospital outbreaks thatcoan cause significant morbidity and mortality, especialty in young infants.

In conclusion, the health personnel sampled showed mostly the absence of protective antibodies against B. pertussis. Moreover, antibody titers suggestivêe of recent asymptomatic infection were found in about $90 \%$ of the staff. Both findings suggest that health persofinel are at risk of infection and, especially, of transmitting it to infants treated in the hospital, who may undergo serious complications or even die from this cause. This study is relevant because it provides evidence to suggest that current vaccination policies need to be modified to dictate the mandatory nature of vaccination. Moreover, measures to prevent the transmission of $B$. pertussis in health personnel who attend pediatric population should be strengthened to prevent disease transmission, especially to vulnerable populations?

\section{Ethical disclosures}

Protection of human and animal subjects. The authors declare that no experiments were performed on humans or animals for this study. 
Confidentiality of data. The authors declare that they have followed the protocols of their work center on the publication of patient data.

Right to privacy and informed consent. The authors have obtained the written informed consent of the patients or subjects mentioned in the article. The corresponding author is in possession of this document.

\section{Conflicts of interest}

The authors declare no conflicts of interest.

\section{Funding}

Hospital Infantil de México Federico Gómez.

\section{References}

1. Beltrán Silva S, Cervantes Apolinar Y, Cherry JD, Geffen D, Conde González C, Gentile A, et al. Consenso para el diagnóstico clínico y microbiológico y la prevención de la infección por Bordetella pertussis. Salud Publica Mex. 2011;53:57-65

2. Alexander EM, Travis S, Booms C, Kaiser A, Fry NK, Harrison TG, et al. Pertussis outbreak on a neonatal unit: identification of a healthcare worker as the likely source. J Hosp Infect. 2008;69:131-4.

3. Centers for Disease Control and Prevention. Pertussis home page. Outbreaks. Available from: http://www.cdc.gov/pertussis/outbreaks.html.

4. World Health Organization. Background paper. SAGE April 2014;2014:82. Available from: http://www.who.int/immunization/sage/meetings/2014/ april/1_Pertussis_background_FINAL4_web.pdf?ua=\%0Ahttp://www. who.int/immunization/sage/meetings/2014/april/1_Pertussis_background_FINAL4_web.pdf.

5. World Health Organization. Pertussis vaccines: WHO position paperSeptember 2015. Wkly Epidemiol Rec. 2015;90(35):433-58.

6. Yeung KHT, Duclos P, Nelson EAS, Hutubessy RCW. An update of the global burden of pertussis in children younger than 5 years: a modelling study. Lancet Infect Dis. 2017; 17:974-80.
7. Hewlett E, Edwards K. Pertussis-not just for kids. N Engl J Med. 2005;352:1215-22

8. Winter K, Zipprich J, Harriman K, Murray EL, Gornbein J, Hammer SJ et al. Risk factors associated with infant deaths from pertussis: ${ }^{-a}$ case-control study. Clin Infect Dis. 2015;61:1099-106.

9. Maltezou HC, Ftika L, Theodoridou M. Nosocomial pertussis in neonatal units. J Hosp Infect. 2013;85:243-8.

10. Follmann D, Qin J, Guerrero ML, Breugelmans JG, Rosales Pedràza G, Gessner BD, et al. Estimating the burden of pertussis in Mexican adolescents from paired serological data by using a bivariate mixture model. J R Stat Soc Ser C Appl Stat. 2014;63:621-37.

11. Wirsing von König $\mathrm{CH}$, Halperin S, Riffelmann M, Guiso N. Pertussis of adults and infants. Lancet Infect Dis. 2002;2:744-50.

12. Wendelboe AM, Van Rie A, Salmaso S, Englund JA. Duration of - immunity against pertussis after natural infection or vaccination. Pediatr Infect Dis J. 2005:24:58-61.

13. Centro Nacional para la Salud de la Infancia y Adolescencia. México: Programa Sectorial de Salud; 2018. Programa de acción especifico vacunación universal. Available from: http://www.censia.salud.gob.mx/ contenidos/descargas/transparencia/especiales/PAE_Vacunacion_Universal_PAE_final_final.pdf.

14. Zouari A, Smaoui $H$, Kechrid $A$. The diagnosis of pertussis: which method to choose? Crit Rev Microbiol. 2012;38:111-21.

15. Cunegundes KSA, de Moraes-Pinto MI, Takahashi TN, Kuramoto-DAB, Weckx LY. Bordetella pertussis infection in paediatric healthcare-workers. J Hosp Infect. 2015;90:163-6.

16. Conde-Glez C, Lazcano-Ponce E, Rojas R, DeAntonio R, Romanō-Mazzotti L, Cervantes Y, et al. Seroprevalence of Bordetella pertussis in the Mexican population: a cross-sectional study. Epidemiol Infect. 2014;142:706-13.

17. Deville JG, Cherry JD, Christenson PD, Pineda E, Leach CT, Kunhts TL, et al. Frequency of unrecognized Bordetella pertussis infections in àdults. Clin Infect Dis. 1995;21:639-42

18. Rodríguez de la Pinta ML, Castro Lareo MI, Ramon Torrell JM, García de Lomas J, Devadiga R, Reyes J, et al. Seroprevalence of pertussis amongst healthcare professionals in Spain. Vaccine. 2016;34:1109-14.

19. De Serres G, Shadmani R, Duval B, Boulianne N, Dery P, Fradeu MD, et al. Morbidity of pertussis in adolescents and adults. $\mathrm{J}$ Infect Dis. 2000;182:174-9.

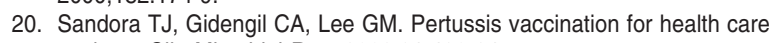
workers. Clin Microbiol Rev. 2008;21:426-34.

21. Bechini A, Tiscione E, Boccalini S, Levi M, Bonanni P. Acellular pertussis vaccine use in risk groups (adolescents, pregnant women, newborns, and health care workers): a review of evidence and recommendations, Vaccine. 2012;30:5179-90.

22. Esolen LM, Kilheeney KL. A mandatory campaign to vaccinate health care workers against pertussis. Am J Infect Control. 2013;41:740-2. 